\title{
Stay special
}

With age comes ...?

\section{Susan Lanigan}

Merlin's stepmother Alison looks like the girl in the huge wall-to-wall infomercials that flash and reload in the city's shopping centres. All the girls look like her, allowing for differences in hair and skin colour.

"Love you too", she says to her girlfriend on the phone. "Stay special."

"What does that mean?" Merlin asks when she hangs up.

She glares at him. "What?"

"When you say 'stay special??"

"You shouldn't listen to other people's phone conversations."

He's known he would get into trouble for asking. Alison, like his mother, does not like to be asked the wrong questions. Where do babies came from? What's the Deterioration?

"Don't ask Alison questions like that," his father always says.

Three years ago, when his mother was still alive, she disappeared one day and Merlin wandered into the nearest Women's Municipal Powder Room in search of her. He remembers passing through a long, tiled vestibule into the main room, where jets of fragrant fog came out of holes placed high up in the walls. To his left and right, in long aisles, stood line after line of dressing-room tables; all along these aisles, women looked into long mirrors, patting their skins with lavender-smelling creams in opaque glass jars, some crying. Eventually, he saw his mother over in the far corner. She was guiding his sister though a similar routine. "See... like this." And then she leaned over and whispered: "Stay special, darling, always ... stay special."

"Stay special," his sister echoed, her thumb in her mouth.

"Mama!" he cried out. His mother turned around, her face darkening. Quickly she picked him up and marched him outside, Lena running along behind, and murmured the same word again and again under her breath: Deterioration.

Alison has taken him shoe-shopping. "Merlin!" she shouts. "Stop wandering off!"

But Merlin has seen something odd in the mall's atrium. Alongside the fountain and palm trees, a hunched figure drags its body towards the café near the entrance. It looks like nothing Merlin has ever seen before. It looks barely human.
"Alison," he calls.

"Can't it wait? I'm kinda busy here."

"There's a funny person in the mall!"

Alison leaps to her feet and races to the window. When she sees the bent figure, she lets out a sudden shriek that sets Merlin's heart racing even before she grabs him and pulls him away, almost causing him to pee in his pants as she drags him to the car.

"What's going on?" he says, as she floors it down the highway.

"Shut up, Merlin."

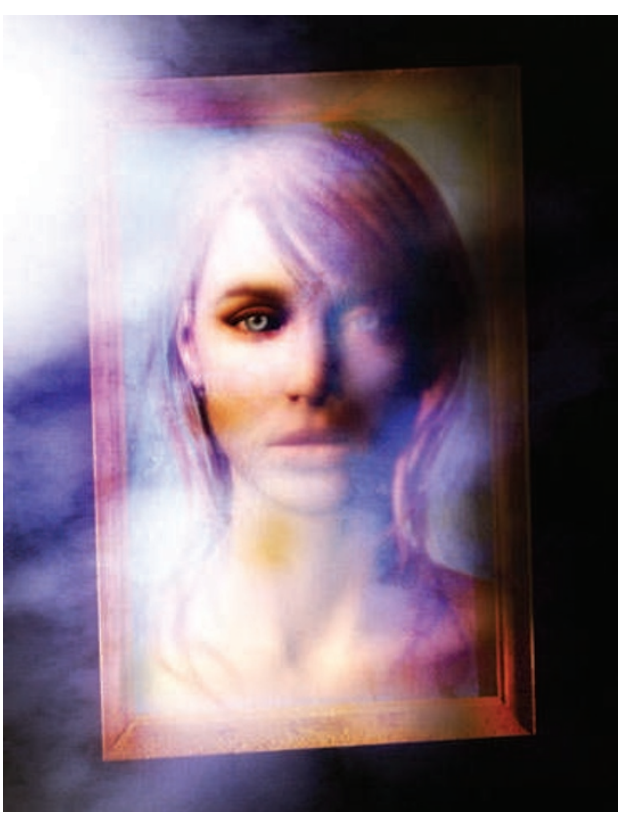

He shrinks into the seat.

"A real-life Degraded woman," she wonders out loud. "I didn't think there were any left."

"What's 'Degraded'?"

"Degraded is when the Deterioration isn't caught in time and it progresses to a stage when - a stage when you look like that."

"But what's the -"

Alison switches on the radio to stop him asking any more questions. On comes a crooning, mellifluous voice announcing a new face cream. Life can be tough, it says. We all know that changes can occur. But today's woman can stay safe for longer. Then it chants the chemical compounds: idebenone, dibenzoylmethane, dithiolane3-pentanoic acid. Then the wrap: Women of the world, remember! Stay special.

Later, in his room, Merlin hears a gentle knock. He opens the door: it is his father with Alison behind him.
"I hear you had a little trouble earlier," Merlin's father says.

"What's the Deterioration?" Merlin blurts out. There is a silence, but he continues. "No, really, what is it? Everyone talks about it and I don't know what it means. I don't know why she's mad at me." Merlin is tearful.

His father tightens his arm around Alison's shoulders. "The Deterioration," he says heavily, "is a name given by women to the condition of senescence. Simply put, growing older."

"So does that mean I'll get it?"

His father sighs. "Merlin, older age in men is seen as normal. As you can see, I ..." His voice trails off. He takes a gulp of his drink.

"They - women - have this rough rule that it starts at the first sign of deep lines around the female mouth. About early-to-mid-thirties. Now I think that's an obscene way of looking at it. Obscene." The ice cubes in his father's glass clatter with his indignation. For the first time, Merlin sees how wrinkled his hand is on Alison's shoulder.

"In the last few years of her life, your mother was severely pressured by the Sisters of her group. I told her not to listen, of course. But she wouldn't hear of it. One day she snuck out of the house early with Lena and presented them both to the Women's Municipal Powder Room - on a suitable day." His father's eyes water.

"Suitable?" Merlin asks.

"Weren't you paying attention when you sneaked off to that Powder Room without permission?" Alison is harsh as a saw. "It's not just nice, sweet-smelling stuff they pump in through those little holes."

"Come with me, Alison," his father murmurs, moving away. Alison turns to look at her stepson, trying to smile - but it is a rictus grin, her eyes like glass.

On his bedroom windowsill, a photograph of Merlin's mother and sister looks down at him. Merlin puts his hand on the picture. The glass is gathering dust.

Slowly, reverently, he wipes it off with his fingers and looks again: first at the woman who has stopped Deteriorating forever, then at the little girl who never started.

"Stay special, Mama. Stay special, Lena. Love you both, stay special."

Susan Lanigan is a programmer and writer. She lives on the east coast of Ireland near Dublin, and blogs at www.joyofwriting.net. 